\title{
HEAVY METALS IN VINEYARDS AND ORCHARD SOILS ${ }^{1}$
}

\author{
GUSTAVO BRUNETTO ${ }^{2}$, PAULO ADEMAR AVELAR FERREIRA ${ }^{3}$, \\ GEORGE WELLINGTON MELO $^{4}$, CARLOS ALBERTO CERETTA ${ }^{5}$, MORENO TOSELLI ${ }^{6}$
}

\begin{abstract}
The application of foliar fungicides in vineyards and orchards can increase soil concentration of heavy metals such as copper $(\mathrm{Cu})$ and zinc $(\mathrm{Zn})$, up to the toxicity threshold for fruit trees and cover crops. However, some agronomic practices, such as liming, addition of organic fertilizers, cultivation of soil cover crops and inoculation of young plants with arbuscular mycorrhizal fungi can decrease the availability and the potential of heavy metal toxicity to fruit trees. This review aims to compile and present information about the effects of increasing concentrations of heavy metals, especially $\mathrm{Cu}$ and $\mathrm{Zn}$, on soils cultivated with fruit trees and provides some agronomic practices of remediation. Information about the sources of heavy metals found in soils cultivated with fruit trees are presented; mechanisms of absorption, transport, accumulation and potential toxicity to plants are described.
\end{abstract}

Index terms: Trace element, phytotoxicity, growth, fruit trees.

\section{METAIS PESADOS EM SOLOS DE VINHEDOS E POMARES}

RESUMO - A aplicação de fungicidas foliares em vinhedos e pomares pode incrementar os teores de metais pesados, como o cobre $(\mathrm{Cu})$ e o zinco $(\mathrm{Zn})$, em solos e, quando em excesso, podem causar toxidez às frutíferas ou plantas de cobertura. Porém, algumas práticas agronômicas, como a calagem, adição de resíduos orgânicos, cultivo de plantas de cobertura do solo e inoculação de plantas jovens com fungos micorrízicos arbusculares (FMA) podem diminuir a disponibilidade e o potencial de toxidez de metais pesados às frutíferas. A presente revisão objetivou compilar e apresentar informações sobre os efeitos do aumento dos teores de metais pesados, especialmente, $\mathrm{Cu}$ e $\mathrm{Zn}$, em solos cultivados com frutíferas e algumas práticas agronômicas de remediação. Ao longo do texto são apresentadas informações sobre as fontes de metais pesados, com enfase no $\mathrm{Cu}$ e $\mathrm{Zn}$, em solos cultivados com frutíferas; mecanismos de absorção, transporte, acúmulo e potencial de toxidez às plantas. Além disso, são relatadas algumas práticas agronômicas viáveis para remediar o potencial de toxidez de metais pesados em solos cultivados com frutíferas. Com a adoção destas práticas se espera menor disponibilidade de metais pesados no solo, o que reduziria o potencial de toxidez às plantas, especialmente, em frutíferas jovens transplantadas em solos com alto teor de metais pesados, como o $\mathrm{Cu}$ e $\mathrm{Zn}$, permitindo satisfatório crescimento, produção e composição de frutos.

Termos para indexação: Elemento traço, fitotoxidez, crescimento, frutíferas.

\footnotetext{
${ }^{1}$ (Paper 226-15). Received on: September 29, 2015. Accepted for publication on: March 01, 2016.

${ }^{2}$ Agronomist, Doctor in Soil Science, Professor of Soil Science and Plant Nutrition, Department of Soil Science and Graduate Studies Program in Soil Science of the Universidade Federal de Santa Maria (UFSM), C.P. 221, CEP 97105-900, Santa Maria-RS, Brazil. Fellowship Holder in Research Productivity from the CNPq. E-mail: brunetto.gustavo@gmail.com

${ }^{3}$ Agronomist, Doctor in Soil Science, Post-doctoral student at Graduate Studies Program in Soil Science (PPGCS), Department of Soil Science of the Universidade Federal de Santa Maria (UFSM), C.P. 221, CEP 97105-900, Santa Maria-RS, Brazil. E-mail: avelarufla@ gmail.com

${ }^{4}$ Agronomist, Doctor in Soil Science and Plant Nutrition, Researcher of the Embrapa Uva e Vinho, Cx. Postal 130, CEP 95700-000, Bento Gonçalves-RS, Brazil. E-mail: wellington.melo@embrapa.br

${ }^{5}$ Agronomist, Doctor in Soil Science, Professor of Soil Science, Department of Soil Science and Graduate Studies Program in Soil Science of the Universidade Federal de Santa Maria (UFSM), C.P. 221, CEP 97105-900, Santa Maria, RS, Brazil. Fellowship Holder in Research Productivity from the CNPq. E-mail: carlosceretta@gmail.com

${ }^{6}$ Agronomist, Professor of Department of Agricultural Sciences, University of Bologna, viale Fanin, 46, 40127, Bologna, Italy. E-mail: moreno.toselli@unibo.it
} 


\section{INTRODUCTION}

Heavy metal is a term often used to name a group of metals and semimetals (metalloids), which are associated with pollution and potential toxicity or ecotoxicity (DUFFUS, 2002). The heavy metals that are often associated with environmental contamination and toxicity to plants and microorganisms in the soil are arsenic (As), cadmium $(\mathrm{Cd})$, chromium $(\mathrm{Cr})$, lead $(\mathrm{Pb})$, mercury $(\mathrm{Hg})$, nickel $(\mathrm{Ni})$, copper $(\mathrm{Cu})$ and zinc $(\mathrm{Zn})$, among others (NAGAJYOTI et al., 2010).

Heavy metals in soils of vineyards and orchards may be derived from natural sources such as weathering of rocks, but also from agricultural practices such as the application of chemical and organic fertilizers, used as source of nutrients for plants. However, in these cases, the main source of heavy metals are foliar fungicides used for control of diseases in fruit trees. The Bordeaux mixture $\left(\mathrm{Ca}(\mathrm{OH})_{2}+\mathrm{CuSO}_{4}\right)$, one of the most commonly used fungicides, is a source of $\mathrm{Cu}$, while products with the active ingredient Mancozeb $\left(\left(\mathrm{C}_{4} \mathrm{H}_{6} \mathrm{MnN}_{2} \mathrm{~S}_{4}\right)\right.$ (Zn)) are sources of Zn (BRUNETTO et al., 2014a; GIROTTO et al., 2014). With the accumulation of heavy metals in soils cultivated with fruit trees, especially above the adsorption capacity of the soil, losses are expected, causing contamination of surface and subsurface waters. Also a great potential for toxicity to fruit trees, vines and cover crops used in orchard (BRUNETTO et al., 2011; 2014a) should be considered.

The high levels of heavy metals such as $\mathrm{Cu}$ and $\mathrm{Zn}$ in the soil can cause shortening and thickening of the root apex of fruit trees and vine (AMBROSINI et al., 2015), increase in the number of lateral roots and plasmolysis in the epidermis of some cells, thus reducing the density of root hairs (CHEN et al., 2013; ZHANG et al., 2014). The excess of $\mathrm{Cu}$ in plants shoots can decrease the concentration of photosynthetic pigments and the rate of $\mathrm{C}$ fixation, and can increase the oxidative stress at cellular level (CAMBROLLÉ et al., 2013; CAMBROLLÉ et al., 2015). All this conditions can reduce fruit tree absorption of water and nutrients, whith change of nutrient concentration within the plant, lower growth, especially in young fruit trees, transplanted in soils with high concentration of $\mathrm{Cu}$ (TOSELLI et al., 2009; MIOTTO et al., 2014). In addition, transport and accumulation of heavy metals to the fruits may have negative effects on the productivity and composition of the crops, and finally on human health.

However, the toxicity of heavy metals such as $\mathrm{Cu}$ and $\mathrm{Zn}$ in soils cultivated with fruit trees can be reduced by the adoption of some agronomic practices, including soil addition of lime, fertilizers, organic products, the cultivation of cover crops in orchard rows and interrow, and the inoculation of young fruit trees with arbuscular mycorrhizal fungi (AMF) before transplantation (FERREIRA et al., 2014; AMBROSINI et al., 2015). This review aims to compile and present information about the effects of increasing concentrations of heavy metals (especially $\mathrm{Cu}$ and $\mathrm{Zn}$ ), in orchard and vineyard soils and to provide some agronomic practices of remediation.

\section{SOURCES OF HEAVY METALS IN VINEYARDS AND ORCHARD SOILS}

Heavy metals such as $\mathrm{Cu}$ and $\mathrm{Zn}$ can be derived from natural sources such as the weathering of rocks, deserts and sea mist, both carried by the wind, the emission of gases and particles from volcanoes (NAGAJYOTI et al., 2010; FERREIRA et al., 2014).

The application of chemical fertilizers, a common practice in vineyards and orchards, can be a source of heavy metals; it is the case of phosphate fertilizers, often reach of impurities that contains heavy metals such as $\mathrm{Cd}, \mathrm{Hg}$ and $\mathrm{Pb}$ (RAMALHO et al., 1999; NAGAJYOTI et al., 2010). The contamination potential depends, among other factors, on the dose and the frequency of application, and on the ability of tree species to accumulate these contaminants in fruits and wood removed from the orchard. Although results on this topic in soils of vineyards and orchards in Brazil are still scarce, in general heavy metals present low mobility that prevent them to be removed from the soil.

On the other hand, the accumulation of heavy metals in soils of vineyards and orchards is promoted by continued applications of organic byproducts such as manure of animals fed with a diet that typically is reach in heavy metals (GRÄBER et al., 2005). Soil application of animal manure (liquid and solid) and organic compound have caused the accumulation and the modification of the distribution of heavy metal fractions in soils cultivated with annual crops and pastures (GIROTTO et al., 2010; TIECHER et al., 2013). The same can happen in vineyards and orchards, in conventional, integrated or organic production system, which have a long history of organic fertilizer applications; especially when the doses added to the soil are defined without technical criteria. In Brazil there are only a few studies on the long term effect of organic waste applications on the increase of heavy metal concentrations and modifications of their fractions in soils of vineyards 
and orchards.

The main source of $\mathrm{Cu}$ and $\mathrm{Zn}$ in grapevine (Vitis sp.), apple (Malus domestica) and other fruit tree orchards, are fungicides used for control of diseases, which can cause the accumulation and changes in the distribution of fractions of these elements in the soil. This happens because of the unidirectionality of applications in plants, through rinsing of heavy metals from the leaves during rain or irrigation, the abscission of senescent leaves or the deposition of pruned branches on the soil (KOMÁREK et al., 2010; BRUNETTO et al., 2014b; MIOTTO et al., 2014). For example, in vineyards, for the preventive control of diseases, especially of downy mildew (Plasmopara viticola), $30 \mathrm{~kg} \mathrm{Cu} \mathrm{ha}^{-1}$ yearr $^{-1}$ may be added to the production system through fungicides (CASALI et al., 2008). This amount can be even larger in years with high frequency and volume of water precipitation, which favors the occurrence of diseases. The potential risk of soil and water contamination with $\mathrm{Cu}$ prompted the European Union (EU) to restrict the rate of $\mathrm{Cu}$ application to fruit trees. The amount of $\mathrm{Cu}$ allowed every year in disease control by the EU legislation is around $6 \mathrm{~kg} \mathrm{ha}^{-1}$ (in some Country it is even forbidden). Although this limitation, in Italy, higher DTPA-extractable $\mathrm{Cu}$ were found in soils with a history of at least 6 years of cultivation of pear and grapevine when compared with vegetable-cultivated plots. Copper was found in the upper horizon, while at $0.20-0.50 \mathrm{~m}$ soil depth no difference among cultivation was found, because of the calcareous soils responsible for the prompt immobilization of free $\mathrm{Cu}$, that prevent any movements of the cation. Beside the DTPA fraction, also the total $\mathrm{Cu}$ was found higher in pear and vine-cultivated plots compared with vegetable-cultivated soils, because the continuous application of $\mathrm{Cu}$ increased the soil inactive $\mathrm{Cu}$ forms (TOSELLI et al., 2009).

The chemical and physical characteristics of the Italian soils allow to incorporate high amount of $\mathrm{Cu}$ (up to $1000 \mathrm{mg} \mathrm{kg}^{-1}$ ) with no toxic effect on pear tree (TOSELLI et al., 2008) and grapevine (TOSELLI et al., 2009). In fact, after one growing season, a $\mathrm{Cu}$ toxic effect was observed in pear and grape grown in soil with a $90 \%$ sand composition, while no effect on tree growth was found in clayloam soil after an application rate of $1000 \mathrm{mg} \mathrm{Cu}$ $\mathrm{kg}^{-1}$. A soil $\mathrm{Cu}$ toxicity threshold for potted pear trees and grape vines was thus established only in sandy soil. In pear trees, symptoms included a reduction of leaf carbon assimilation, leaf area and shoot growth but no leaf chlorosis or necrosis and appeared with soil $\mathrm{Cu}$ addition higher than 400 $\mathrm{mg} \mathrm{kg}{ }^{-1}$, corresponding to 2 and $350 \mathrm{mg} \mathrm{Cu} \mathrm{kg}{ }^{-1}$ of $\mathrm{CaCl}_{2}$ and DTPA-extractable $\mathrm{Cu}$, respectively. In grapevines, $\mathrm{Cu}$ toxicity was observed after an addition rate of $200 \mathrm{mg} \mathrm{Cu} \mathrm{kg}^{-1}$ corresponding to threshold of 0.78 and $121 \mathrm{mg} \mathrm{Cu} \mathrm{kg}^{-1}$ of $\mathrm{CaCl}_{2}$ and DTPA-extractable $\mathrm{Cu}$, respectively. Above this threshold a reduction of carbon assimilation rate, shoot growth and leaf chlorosis appeared after 2 years of $\mathrm{Cu}$ exposure. Copper accumulated in roots, as a response to soil $\mathrm{Cu}$ additions, according to a linear and a quadratic function for sandy and clayloam soil, respectively, so that root $\mathrm{Cu}$ concentration seemed to be the most appropriate indicator of $\mathrm{Cu}$ bioavailability in both soils. However, most of the $\mathrm{Cu}$ was found in the apoplastic root compartment, adsorbed to the negative charge of the Donnan free space, and showed a possible antagonistic effect against other nutrients such as $\mathrm{Zn}$ (in pear root), $\mathrm{P}$, $\mathrm{Ca}, \mathrm{Mg}, \mathrm{Fe}$ (in vine leaf), $\mathrm{Mn}$ and $\mathrm{Zn}$ (in vine roots), that all decreased as soil $\mathrm{Cu}$ concentration increased. Another explanation of the toxic effect of $\mathrm{Cu}$ in sandy soil is the lower nutritional status of plants than in clay loam soil that made them more susceptible to $\mathrm{Cu}$ antagonism on other nutrients. In both pear and grape, leaf $\mathrm{Cu}$ concentration was not associated with $\mathrm{Cu}$ toxicity. However, in both sand and clay-loam soils, a linear reduction of microbial activity was found in response to the increase of $\mathrm{Cu}$ addition rate, showing a higher susceptibility to $\mathrm{Cu}$ toxicity of soil microbes than tree (TOSELLI et al., 2009).

\section{HEAVY METALS IN SOIL OF VINEYARDS AND ORCHARD}

The distribution of heavy metals in solid phase and soil solution depends on the reactions of precipitation/dissolution, adsorption/desorption and oxireduction. In solution, heavy metals may be in free or complexed form. The complex happens between the metal and an inorganic or organic binder. The formation of stable complexes in the soil solution may retard the adsorption of heavy metals into functional groups of reactive particles surface (ALLEONI et al., 2005; FERREIRA et al., 2014). In solid phase the heavy metal can be adsorbed through mechanisms such as the ion exchange, specific adsorption and complexation with organic material from the soil (ALLOWAY, 1995). The ion exchange adsorption is weak and not very stable. In specific adsorption on functional groups of inorganic particles, a heavy metal such as $\mathrm{Cu}$ loses partially or completely its water of hydration, forming the inner-sphere complex with the surface of oxides, not crystallized aluminosilicates and edges of clay minerals that are 
$\mathrm{OH}^{-}$or a molecule of $\mathrm{H}_{2} \mathrm{O}_{2}$ bound to a metal ion of the crystal lattice (BRADL, 2004; ALLEONI et al., 2005). The bond between heavy metals such as $\mathrm{Cu}$ and organic material can occur by ionic exchange between the $\mathrm{H}^{+}$of functional groups and the ion (ALLEONI et al., 2005). Thus, the availability of $\mathrm{Cu}$ in soils depends on the ligand, the oxides, hydroxides, carbonates, content and composition of the organic matter and on the cation exchange capacity (CEC) (FERNÁNDEZ-CALVIÑO et al., 2010; COUTO et al., 2014; BRUNETTO et al., 2014b).

The adsorption of heavy metals in the soil usually begins in more avid adsorption sites and the remainder may be redistributed into fractions with lower binding energy, therefore, with greater availability (BRUNETTO et al., 2014b). This distribution can be estimated using the chemical fractionation, where different chemical extractants are used sequentially, to remove the elements from more available fractions to those more stable (TESSIER et al., 1979). In this way, the totality of $\mathrm{Cu}$ and $\mathrm{Zn}$ in soil is separated into bioavailable fractions (soluble in water and interchangeable), with potential for bioavailability (related to minerals and organic matter) and not available or residual (mineral structure).

In the literature, it is common to find the total concentrations of heavy metals in soil, in comparison with their fractions. For example, regarding the $\mathrm{Cu}$ in soils of traditional wine-growing regions of the world, 20 to $500 \mathrm{mg} \mathrm{Cu} \mathrm{kg}^{-1}$ are reported in France (FLORES-VÉLES et al., 1996; BRUN et al., 1998); 35 to $600 \mathrm{mg} \mathrm{kg}^{-1}$ in Spain (ARIAS et al., 2004); 2 to $375 \mathrm{mg} \mathrm{kg}^{-1}$ in Italy (TOSELLI et al., 2009); 100 to $210 \mathrm{mg} \mathrm{kg}^{-1}$ in Greece (VAVOULIDOU et al., 2005) and 40 to $250 \mathrm{mg} \mathrm{kg}^{-1}$ in Australia (PIETRZAK; MCPHAIL, 2004). In most cases these $\mathrm{Cu}$ concentrations are related to foliar applications of copper fungicides and, often, may be toxic to plants.

From the chemical fractionation technique it is possible to determine the different labilities of $\mathrm{Cu}$ and $\mathrm{Zn}$ fractions in the soil, and to associate the results to the water contamination potential or to the toxicity to plants. For example, in soils with medium texture and with medium and high organic matter content in Serrra Gaúcha, State of Rio Grande do Sul, which is the largest wine-growing region in Brazil, CASALI et al. (2008) reported that the application of copper fungicides in vineyards increased the total content and the fractions more bioavailable of $\mathrm{Cu}$ in soil, including in layer as deep as $0.20-0.40$ $\mathrm{m}$. Furthermore, the same authors (CASALI et al., 2008) stated that other portions of $\mathrm{Cu}$ were noted adsorbed onto the mineral fraction, and that most of the $\mathrm{Cu}$, regardless of the adsorbent material, was easily desorbable and could be considered in rapid equilibrium with $\mathrm{Cu}$ in the solution. In this case, the toxicity to plants in vineyard (vines or cover crop species) is maximized. Similarly, in Serra Gaúcha soils, increments of mineral $\mathrm{Cu}$, as well as $\mathrm{Cu}$ fractions more bioavailable, along with apparent saturation of the functional groups of soil organic matter was found (GIROTTO et al., 2014). In addition, the fractions extracted by $\mathrm{HCl}$ accounted for $372.7,493.3,240.9$ and $74.7 \mathrm{mg} \mathrm{Cu} \mathrm{kg}^{-1}$ at layers of 0.0-0.5 m, 0.5-0.10 m, 0.10-0.15 $\mathrm{m}$ and 0.15-0.20 $\mathrm{m}$, respectively. These levels are much higher than the $0.4 \mathrm{mg} \mathrm{Cu} \mathrm{kg}^{-1}$ (extracted by $\mathrm{HCl}$, which is established as the threshold high by the Commission of Chemistry and Soil Fertility in the states of Rio Grande do Sul and Santa Catarina - CQFS-RS/SC, 2004). On the other hand, in cambisols of vineyards located in the Midwest region of Santa Catarina, accumulation of $\mathrm{Cu}$ and $\mathrm{Zn}$ in more superficial layers of soil was positively related to vineyard age (BRUNETTO et al., 2014c; COUTO et al., 2014). The same authors reported that most of the $\mathrm{Cu}$ and $\mathrm{Zn}$ concentrations were noted in the residual fraction that is not available; however in soils with a long history of use of copper fungicides, there was an increase in the $\mathrm{Cu}$ bound to the soil organic matter and, in the deepest layers, of $\mathrm{Cu}$ bound to the minerals.

In vineyard soils with sandy texture and low organic matter in the Rio Grande do Sul, BRUNETTO et al. (2014b) found accumulation of $\mathrm{Cu}$ and $\mathrm{Zn}$ in the most superficial layers in soils with 14 and 30 year-old vineyards both with a history of application of Bordeaux mixture and Mancozebbased fungicides. In addition, most of the $\mathrm{Cu}$ was noted in mineral fraction and most of $\mathrm{Zn}$ in mineral and residual fractions. However, it was noted that $73 \%$ of $\mathrm{Cu}$ and $30 \%$ of $\mathrm{Zn}$ in vineyard soils was bioavailable to plants (extracted by EDTA), supplying the demands of the plants, but as the levels in the soil would increase, they could cause toxicity (BRUNETTO et al., 2014b).

Applications of fungicides in other fruit trees, such as apple, can also cause accumulation and modification of heavy metal (i.e. $\mathrm{Zn}$ and $\mathrm{Cu}$ ) fractions in the soil (NEILSEN et al., 1986). (unpublished data) observed accumulation of $\mathrm{Cu}$ and $\mathrm{Zn}$ fractions in the $0.0-0.025 \mathrm{~m}$ layer, especially in the orchard with a long (18 years) history of cultivation and, consequently, frequent applications of $\mathrm{Cu}$ - and $\mathrm{Zn}$-based fungicides. The same authors reported that most of the $\mathrm{Cu}$, especially in the most superficial layer of the orchard soil, was complexed 
in its organic fraction. This is one of the justifications of the importance of maintaining adequate levels of organic matter in the soil, aiming to avoid the increase of bioavailable fractions of $\mathrm{Cu}$, which may potentiate the toxicity to plants, as well as its transfer to subsurface waters. In the same study (unpublished data), it was also observed more stable forms of $\mathrm{Cu}$ in deep soil layers, as residual and mineral fraction, in addition to the $\mathrm{Cu}$ complexed to organic matter. In turn, most of the $\mathrm{Zn}$ was found in the fraction bound to minerals and residual, which indicates low mobility and low potential toxicity to plants.

\section{ABSORPTION, TRANSPORT AND PLANT TOXICITY OF HEAVY METALS}

The bioavailability of heavy metals in the rhizosphere can be influenced by root exudates, organic acids, siderophores and protons. Plants absorb heavy metals from soil solution preferably in ionic forms such as $\mathrm{Zn}^{2+}, \mathrm{Cu}^{2+}, \mathrm{Cd}^{2+}, \mathrm{Pb}^{2+}, \mathrm{Ni}^{2+}, \mathrm{Co}^{2+}$, $\mathrm{Mn}^{2+}$ and $\mathrm{Cr}^{3+}$ and $\mathrm{Cr}^{6+}$. The absorption and transport of these elements are controlled and regulated by a variety of molecules, some of them involved in the trans-membrane transport and some of them involved in their complexation and subsequent sequestration. The absorption of metal ions from the soil solution is mediated by specialized carriers coupled to proteins present in the plasma membrane of root cells. The carriers realize the primary active transport of ions such as $\mathrm{H}^{+}$or $\mathrm{Ca}^{2+}$, generating an electrochemical gradient when transporting ions against a concentration gradient, using energy-rich compounds like ATP for this purpose. The main types of electrogenic pumps are the $\mathrm{H}^{+}$-ATPases of type $\mathrm{P}$ located in the plasma membrane (cell membrane), $\mathrm{H}^{+}$-ATPases of type $\mathrm{V}$ and $\mathrm{H}^{+}$- pyrophosphatases ( $\mathrm{H}^{+}$-PPases), located in the vacuoles membranes (tonoplasts). Another mechanism, named secondary transport of $\mathrm{H}^{+}$, is necessary to direct the active absorption of heavy metals, in which solutes can be transported by the membrane, in favor of an electrochemical gradient through the combination of $\mathrm{H}^{+}$and the ion. This type of co-transport requires energy provided by the proton-motive force, generated by the ATP hydrolysis performed by the $\mathrm{H}$ ${ }^{+}$-ATPases (MORSOMME; BOUTRY, 1999).

The negative membrane potential $(-200 \mathrm{mV})$ within the plasma membrane in epidermal cells of roots (HIRSCH et al., 1998) provides a strong driving force for absorption of cations through secondary carriers. For example, the carriers of heavy metals in plants fall into four different families: as the CPx-ATPases, Nramps, CDF (facilitator of diffusion of cations), and ZIP, which are involved in the absorption of metals and homeostasis in general, playing a key role in tolerance to these elements (SETH, 2012). Non-essential heavy metals can effectively compete with essential metals by the same transmembrane transporters having similar ionic radii oxidation states (ALFORD et al., 2010). This relative lack of selectivity for the transport of trans-membrane ions may partially explain why non-essential heavy metal enter the cells of plants root system, even against a concentration gradient (SETH, 2012).

After their absorption, metal ions can be stored in the roots and/or translocated to the shoot via the xylem (JABEEN et al., 2009). Metals can also have a first apoplastic radial transport in the root, until they reach a first filter of diffusion and regulation in the endoderm, when they must cross the plasmamebrane. Once in the stele, metals move mainly via xylem and, in their relations with adjacent cells, may induce alterations in the differentiation of the vascular system (BARCELÓ; POSCHENRIEDER, 1992). Species or varieties of the same plant species, exposed to a similar concentration of heavy metals, may show a different absorption rate and/or internal distribution in the plant. This may result in differences in the retention capability of the element absorbed in the roots or in the variation in the xylem load (SHAW, 1989).

After the symplast absorption, three processes govern the movement of the metals from root to shoot via the xylem: sequestration of metals inside the cells of the roots, symplastic transport in the stele and release into the xylem. The transport of the metal ions in the xylem is usually a strictly controlled process, mediated by membrane transport proteins. Due to the reactivity of metal ions with functional groups - $\mathrm{OH},-\mathrm{COO}^{-},-\mathrm{SH}$, and $-\mathrm{NH}_{2}$, carboxylic acids and amino acids represent potential ligands of heavy metals. Some carboxylic acids (citric, malic and oxalic acid) are involved in various processes, including transport through the xylem and vacuolar sequestration (RAUSER, 1999). In regard to amino acids produced by plants in response to the presence of heavy metals, histidine is involved in transport of Ni. The presence of high amounts of histidine, may increases up to 50 times the rate of $\mathrm{Ni}$ transport in the xylem. Thus, the chelation of metal ions by histidine, nicotianamine (PICH et al., 1994) and citrate (SENDEN et al., 1995) appears to be the major route of translocation of metals via the xylem. Inside the xylem, the transport of metal ions depends on the $\mathrm{pH}$ balance existing between the organic chelants of low molecular weight and the hydrated free metal 
ions. Furthermore, the mobility of chelated metals depends on the flow of transpiration and also on the metals bound to the cell wall surrounding the xylem vessels (SENDEN; WOLTERBEEK, 1990).

The response of plants to heavy metal toxicity involves structural, biochemical and physiological changes that depend on the type and concentration of the elements and on the time of plant exposure to such elements (Figure 1). Considering the physiological actions, there are a number of factors to consider like the mechanisms of absorption, transport and accumulation of elements in plant tissues. The primary mechanisms of toxicity are found at molecular, cellular and sub-cellular level; the secondary mechanisms of interference deal with functional processes of plants and homeostatic response mechanisms which, in some cases, lead to tolerance mechanisms to heavy metal (BARCELÓ; POSCHENRIEDER, 1992).

In general, the most visible symptom of phytotoxicity for heavy metals includes: reduced growth, especially of the root system, chlorosis and necrosis on the leaves and, subsequently, typical symptoms of senescence and abscission (BRECKLE; KAHLE, 1992; PUNZ; SIEGHARDT, 1993) (Figure 1). Vines and cover crops grown in vineyard soils with high concentration of $\mathrm{Cu}$ have roots with shorter and thicker root apex, because of the changes in cell division and in the arrangement of tissues (AMBROSINI et al., 2015). The number of lateral roots can increase and in the epidermis plasmolysis of some cells can occur, with a reduction of the density of root hair normally observed (ZHANG et al., 2014). Changes in morphology and anatomical structure of the roots can be reflected in reduced absorption of nutrients and water by plants, reduced growth and root and shoot biomass (TOSELLI et al., 2009; MIOTTO et al., 2014).

Excessive $\mathrm{Cu}$ in the shoot of cultivated trees can lead to a lower photosynthetic pigment concentration and decrease photosynthesis rate (CAMBROLLÉ et al., 2013; 2015). The reduction of photosynthesis, accompanied by slower growth rate of the plant, causes the accumulation of carbohydrates and starch in leaves, due to the lower demand for energy (ALAOUI-SOSSÉ et al., 2004). Furthermore, high $\mathrm{Cu}$ concentration in the vines tissue can cause oxidative stress at the cellular level, with an increase of reactive oxygen species (ROS), as superoxide anion $\left(\mathrm{O}^{2--}\right)$, singlet oxygen $\left({ }^{1} \mathrm{O}_{2}\right)$, hydrogen peroxide $\left(\mathrm{H}_{2} \mathrm{O}_{2}\right)$ and hydroxyl radical $\left(\mathrm{OH}^{-}\right.$ ). ROS can damage all biomolecules; in particular lipid peroxidation of the cell membranes is one of the most important observed effects (MIOTTO et al., 2014).

It may also be observed a change in the organization of cells in the root apex, increasing the areas of the cortex and of the vascular cylinder and, consequently, of the root diameter, with a reduction of the growth young vines (AMBROSINI et al., 2015) in soil with sandy texture, low organic matter and high concentration of $\mathrm{Cu}\left(40 \mathrm{mg} \mathrm{kg}^{-1}\right.$ of EDTA extractable $\mathrm{Cu}$ ). Moreover, the same authors reported that exposure to $\mathrm{Cu}$ caused accumulation of phenolic compounds in the cortex cells of the root apex, reduction of the calcium concentration in the roots and increase of $\mathrm{Cu}$ concentration and accumulation in roots. In the same plants, the high $\mathrm{Cu}$ soil concentration modified $\mathrm{CO}_{2}$ assimilation, stomatal conductance and transpiration (ROSA et al., 2014). These results explain in part the slow growth rate of young vines exposed to high $\mathrm{Cu}$ concentration. On the other hand, in the same conditions, adult bearing grapevines, showed an increasing leaf $\mathrm{Cu}$ concentration and evidence of oxidative stress, with no change in the nutritional status of the vines (MIOTTO et al., 2014).

\section{AGRONOMIC PRACTICES TO REDUCE THE TOXICITY OF HEAVY METALS IN VINEYARDS AND ORCHARD SOILS}

As noted earlier, there are numerous situations where levels of heavy metals in soils are high, and requires remediation strategies. These strategies generally include processes that aim at reducing metal concentration and solubility, in order to reduce uptake and attenuate the toxic effects on biological systems (Figure 2). Some practices that may be viable in vineyard and orchard soils are: 1) addition of lime, fertilizers (expecially phosphate), organic by-products, 2) use of cover crop species and 3) promotion of arbuscolar mycorrhizal fungi (AMF) symbiosis.

The addition of lime in contaminated soils of vineyards and orchards in production or after their removal promotes the increase of $\mathrm{OH}^{-}$concentration in solution, encouraging the deprotonation of $\mathrm{H}^{+}$ from the surface of functional groups, which, in turn, promotes the increase of the of CEC and the adsorption of $\mathrm{Cu}$, decreasing its concentration in soil solution and its potential toxicity (AMBROSINI et al., 2015). In addition, $\mathrm{OH}^{-}$in the solution, derived from lime dissociation, can react with $\mathrm{Cu}$, forming $\mathrm{Cu}$ hydroxide which precipitates and, therefore, reduce the activity of free $\mathrm{Cu}$ species in solution. Also, the addition of lime increases the content of interchangeable $\mathrm{Ca}$ and $\mathrm{Mg}$ in the soil, which can 
decrease the toxic effects of $\mathrm{Cu}$. The increase of $\mathrm{Ca}$ concentration within the plant alleviates the possible changes caused by $\mathrm{Cu}$ in the anatomy of the roots (CHEN et al., 2013; AMBROSINI et al., 2015).

Various slags, especially those rich in silicates, have been studied for the effect of reduction of mobility of metals by means of changes in soil $\mathrm{pH}$ (LI et al., 2008). The basic slag is made of Ca- and $\mathrm{Mg}$-silicates that act as corrective of soil acidity, are sources of Si and alleviate the toxicity of metals in the soil (KIRKHAM, 2006; FERREIRA et al., 2013). Although $\mathrm{Si}$ is not recognized as an essential element for fruit trees, it has proven beneficial effects for many species (MA \& YAMAJI, 2008). For example, Si has increased tolerance of the plants to the toxicity of $\mathrm{Mn}, \mathrm{Fe}, \mathrm{Cd}$ and $\mathrm{Zn}$ (CUNHA et al., 2008; ZHANG et al., 2008; FERREIRA et al., 2013).

The addition of organic fertilizer, such as the compost derived from the aerobic or anaerobic stabilization of agri-food wastes (fruit and vegetable after juice production, sawdust and poultry slaughter), especially when added to degraded soils, can contribute to increase the content of soil organic matter. This can lead to the complexation with heavy metals that present an electron configuration [Ar] $3 \mathrm{~d}^{10} 4 \mathrm{~s}^{1}$ that allows a high reactivity with the organic matter functional groups containing $\mathrm{S}$ and $\mathrm{N}$, as well as carboxylics and phenolics, which allows a high bound power and low dessorption (CASALI et al., 2008). On the other hand, the mineralization of organic waste produces molecules into the soil solution that can complex heavy metals (such as $\mathrm{Cu}$ ) and reduce their bioavailability and therefore the toxicity, but can increase their mobility through soil profile, which is not always desirable (BRUNETTO et al., 2014b).

Cover crops cultivated in row and interrow of vineyards and orchards with high levels of heavy metals can decrease their availability through the absorption and compartmentalization in the apoplast of roots or organelles, such as the vacuole (CHAIGNON; HINSINGER, 2003). In addition, plants can also alter the $\mathrm{pH}$ of the rhizospheric soil, which is reflective of the release of $\mathrm{H}^{+}, \mathrm{OH}^{-}$, $\mathrm{HCO}_{3}^{-}$in order to keep electrochemical balance of roots when plants absorb cations or anions. When absorption of anion is greater than cation there is an increase of the rhizospheric soil $\mathrm{pH}$, that promotes the complexation and therefore the precipitation of $\mathrm{Cu}$ and other metals, which reduces the percentage of free species of heavy metal in solution, hence its toxicity to plants. Low molecular weight organic acids, such as citric, malic, fumalic can be exuded by the roots of plants, including vines (COVARRUBIAS et al., 2012). At the same time organic acids may derive from organic matter (root or shoot residues) decomposition, promoted by microorganisms (PII et al., 2015). The dissolved organic compounds in the soil solution have a high affinity with heavy metals, reducing the potential toxicity for plants (JONES; DARRAH, 1994; MEIER et al., 2012; PÉREZESTEBAN et al., 2014).

The mutualistic association between AMF and plant roots can also be a way of minimizing the toxic effects of heavy metals in contaminated soils of fruit trees. In this context, associations between plants and AMF are of great importance because AMF improves $\mathrm{P}$ uptake, assist in plant growth, and may also contribute to reduce the availability of heavy metals as a result of their immobilization in fungal structures or glomalin (ABDEL LATEF, 2013; GIL-CARDEZA et al., 2014). This latter effect results in a decrease in the transfer of potentially toxic elements from roots to shoots (JONER et al., 2000; CHRISTIE et al., 2004). AMF may also reduce heavy metal uptake by promoting the precipitation or chelation of elements in the rhizosphere (KALDORF et al., 1999) and by promoting morphological, physiological and molecular changes in host plants (ANDRADE et al., 2010). 

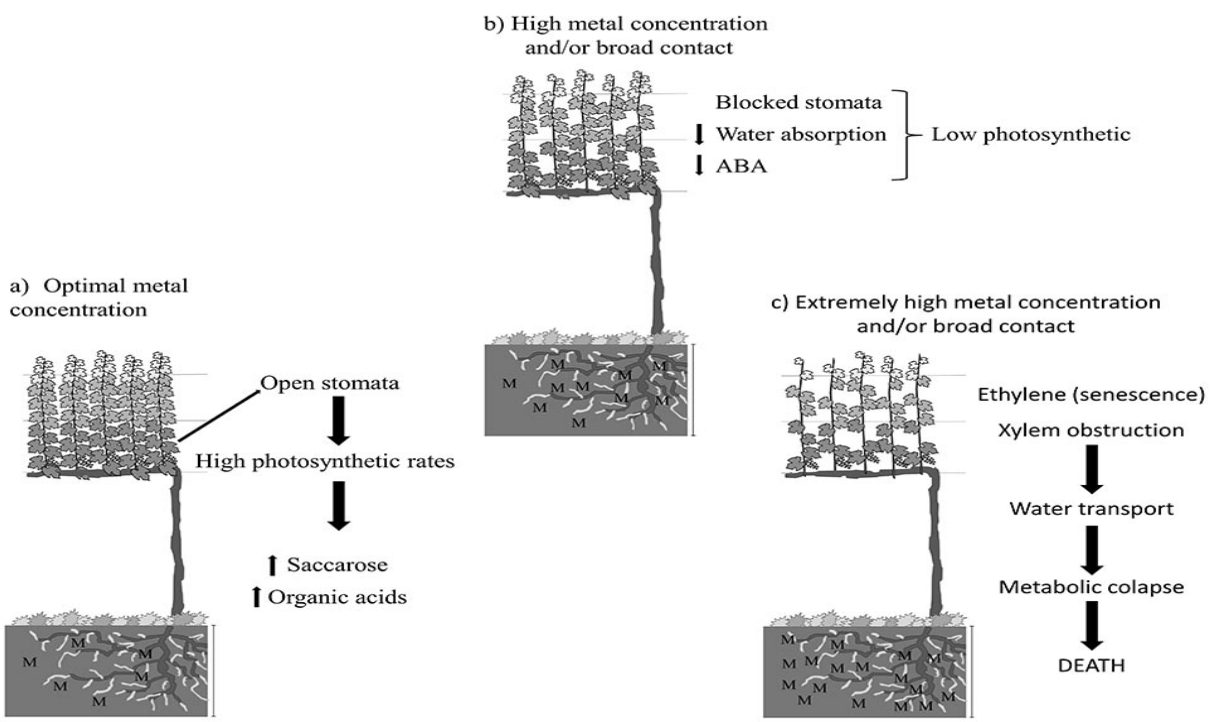

FIGURE 1- Schematical representation of a mechanism of plant physiological responses to heavy metal toxicity: influence of metallic ion concentration and time of contact (Based on BARCELÓ; POSCHENRIEDER (1992)). Abbreviations and symbols: ABA = abscisic acid; $\mathrm{M}=$ metal.

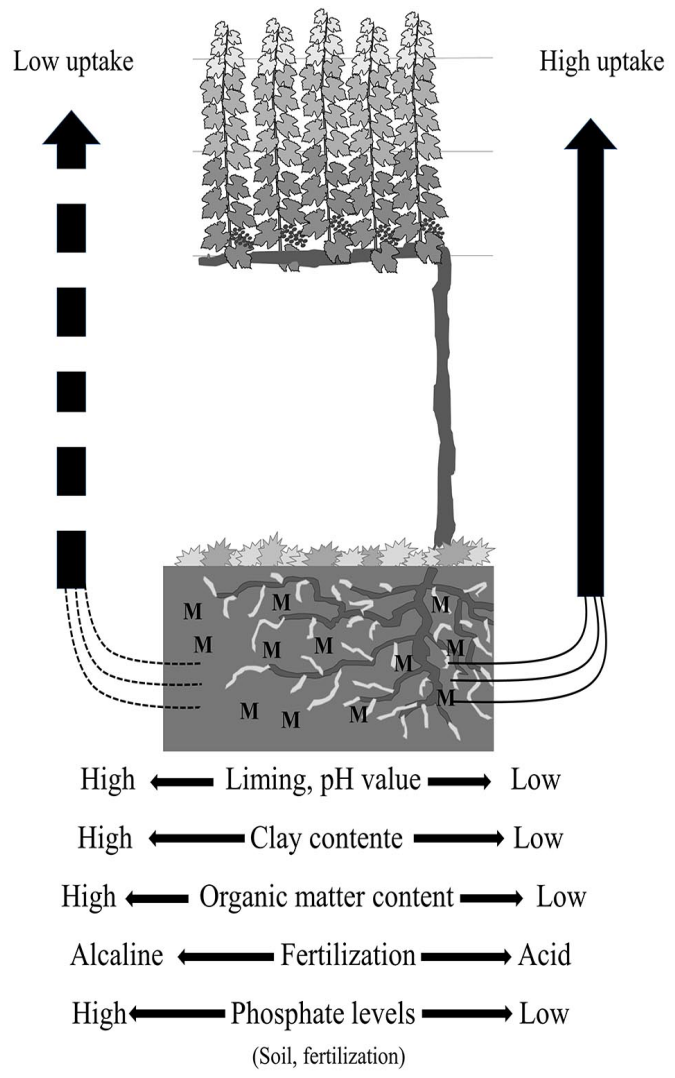

FIGURE 2- Factors that affect soil heavy metal availability. Arrow size and thickness indicate relative contribution of each factor in the absorption of metals by plants. Interrupted lines indicate limited uptake (Modified from BERGMANN, 1992, with permission). Symbols: M = metal. 


\section{REFERENCES}

ABDEL LATEF, A.A. Growth and some physiological activities of pepper (Capsicum annuum L.) in response to cadmium stress and mycorrhizal symbiosis. Journal of Agricultural Science and Technology, Libertyville, v.15, p.1437-48, 2013.

ALAOUI-SOSSÉ, B.; GENET, P.; VINIT-DUNAND, F.; TOUSSAINT, M.L.; EPRON, D.; BADOT, P.M. Effect of copper on growth in cucumber plants (Cucumis sativus) and its relationships with carbohydrate accumulation and changes in ion contents. Plant Science, New York, v.166, p.1213$8,2004$.

ALFORD, E.R.; PILON-SMITS, E.A.H.; PASCHKE, M.W. Metallophytes-a view from the rhizosphere. Plant and Soil, New York, v.337, p.33-50, 2010.

ALLEONI, L.R.F.; BORBA, R.P.; CAMARGO, O. A. Metais pesados: da cosmogênese aos solos brasileiros. In: TORRADO-VIDAL, P.; ALLEONI, L.R.F.; COOPER, M.; SILVA, A. P. (Ed.). Tópicos em ciência do solo. Viçosa: Sociedade Brasileira de Ciência do Solo, 2005. p.1-42.

ALLOWAY, B.J. Heavy metals in soils. $2^{\text {nd }}$ ed. Glasgow: Blackie Academic \& Professional, 1995. p.368.

AMBROSINI, V.G.; ROSA, D.J.; PRADO, J.P.C.; BORGHEZAN, M.; MELO, G.W.B.; SOARES, C.R.F.S.; COMIN, J.J.; SIMÃO, D.G.; BRUNETO, G. Reduction of copper phytotoxicity by liming: a study of the root anatomy of young vines (Vitis labrusca L.). Plant Physiology and Biochemistry, Kalyani, v.96, p.270-280, 2015.

ANDRADE, S.A.L.; GRATÃO, P.L.; AZEVEDO, R.A.; SILVEIRA, A.P.D.; SCHIAVINATO, M.A.; MAZZAFERA, P. Biochemical and physiological changes in jack bean under mycorrhizal symbiosis growing in soil with increasing $\mathrm{Cu}$ concentrations. Environmental and Experimental Botany, Amsterdam, v.68, p.18-207, 2010.

ARIAS, M.; LÓPEZ, E.; FERNÁNDEZ, D.; SOTO, B. Copper distribution and dynamics in acid vineyard soils treated with copper-based fungicides. Soil Science, Baltimore, v.169, p.796-805, 2004.
BARCELÓ, J.; POSCHENRIEDER, C.H. Respuestas de las plantas a la contaminación por metales pesados. Suelo y Planta, Madrid, v.2, p.345-61, 1992.

BERGMANN, W. Nutritional disorders of plantsDevelopment, visual and analytical diagnosis. New York: G. Fischer, 1992. p.300.

BRADL, H. Adsorption of heavy metal ions on soils and soils constituents. Journal of Colloid and Interface Science, Orlando, v.277, p.1-18, 2004.

BRECKLE, S.W.; KAHLE, H. Effects of toxic heavy metals $(\mathrm{Cd}, \mathrm{Pb})$ on growth and mineral nutrition of beech (Fagus sylvatica L.). Vegetatio, The Hague, v.101, p.43-53, 1992.

BRUN, L.A.; MAILLET, J.; RICHARTE, J.; HERMANN, P.; REMY, J.C. Relationships between extractable copper, soil properties and copper uptake by wild plants in vineyard soils. Environmental Pollution, Oxford, v.102, p.151-61, 1998.

BRUNETTO, G.; VENTURA, M.; SCANDELLARI, F.; CERETTA, C.A.; KAMINSKI, J.; MELO, G. W.B.; TAGLIAVINI, M. Nutrients release during the decomposition of mowed perennial ryegrass and white clover and its contribution to nitrogen nutrition of grapevine. Nutrient Cycling in Agroecosystems, Boston, v.90, p.299-308, 2011.

BRUNETTO, G.; CERETTA, C.A.; MELO, G.W.B.; KAMINSKI, J.; TRENTIN, G.; GIROTTO, E.; FERREIRA, P.A.; MIOTTO, A.; TRIVELIN, P.C.O. Contribution of nitrogen from agricultural residues of rye to Niagara Rosada grape nutrition. Scientia Horticulturae, New York, v.169, p.66-70, 2014a.

BRUNETTO, G.; MIOTTO, A.; CERETTA, C.A.; SCHMITT, D.E.; HEINZEN, J.; MORAES, M.P.; CANTON, L.; TIECHER, T.L.; COMIN, J.J.; GIROTTO, E. Mobility of copper and zinc fractions in fungicide-amended vineyard sandy soils. Archives of Agronomy and Soil Science, Berlin, v.60, p.609$24,2014 b$.

BRUNETTO, G.; Schmitt, D.E.; COMIN, J.J.; MIOTTO, A.; MORAES, M.P.; Heinzen, J. Frações de cobre e zinco em solos de vinhedos no Meio Oeste de Santa Catarina. Revista Brasileira de Engenharia Agrícola e Ambiental, Campina Grande, v.18, p.805-10, 2014c. 
CAMBROLLÉ, J.; J. L.GARCÍA, J.L.; R.OOCETE, R.; M. E. FIGUEROA, M.E.A; M. CANTOS, M.. Growth and photosynthetic responses to copper in wild grapevine. Chemosphere, Oxford, v.93, p.294$301,2013$.

CAMBROLLÉ, J.; GARCÍA, J.L.; OCETE, R.; FIGUEROA, M.E.; CANTOS, M.CAMBROLLÉ, J.; GARCÍA, J.L.; FIGUEROA, M.E.; CANTOS, M.. Evaluating wild grapevine tolerance to copper toxicity. Chemosphere, Oxford, v.120, p.171-8, 2015.

CASALI, C.A.; MORTELE, D.F.; RHEINHEIMER, D.S.; BRUNETTO, G.; CORSINI, A.L.M.; KAMINSKI, J. Formas e dessorção de cobre em solos cultivados com videira na Serra Gaúcha do Rio Grande do Sul. Revista Brasileira de Ciência do Solo, Viçosa, MG, v.32, p.1479-87, 2008.

CHAIGNON, V.; HINSINGER, P. A biotest for evaluating copper bioavailability to plants in a contaminated soil. Journal of Environmental Quality, Madison, v.32, p.824-33, 2003.

CHEN, P.Y.; LEE, Y.I.; CHEN, B.C.; JUANG, K.W. Effects of calcium on rhizotoxicity and the accumulation and translocation of copper by grapevines. Plant Physiology and Biochemistry, Kalyani, v.73, p.375-82, 2013.

CHRISTIE, P.; LI, X.; CHEN, B. Arbuscular mycorrhiza can depress translocation of zinc to shoots of host plants in soils moderately polluted with zinc. Plant and Soil, New York, v.261, p.20917,2004

COMISSÃO DE QUÍMICA E FERTILIDADE DO SOLO - RS/SC. Manual de adubação e calagem para os Estados do Rio Grande do Sul e de Santa Catarina. 10. ed. Porto Alegre: SBCS - Núcleo Regional Sul/UFRGS, 2004. 400p.

COUTO, R.R; BENEDET, L.; BRUNETTO, G.; COMIN, J.J.; BELLI, F.P.; MARTINS, S.R.; GATIBONI, L.C; RADETSKI, M.; VALOIS, C.M.; AMBROSINI, V.G. Accumulation of copper and zinc fractions in vineyard soil in the mid-western region of Santa Catarina, Brazil. Environmental Earth Sciences, Heidelberg, v.1, p. 2, 2014.

COVARRUBIAS, J.I. Colture arboree ed agrosistemi forestali ornamentali e paesaggistici. 2012. 127f. Tesi (PhD in Fruit Trees and Woody Plant Sciences) - Alma Mater Studiorum - Università di Bologna, Bologna, 2012.
CUNHA, K.P.V. da; NASCIMENTO, C.W.A. do; PIMENTEL, R.M.M.; FERREIRA, C.P. Cellular localization of cadmium and structural changes in maize plants grown on a $\mathrm{Cd}$ contaminated soil with and without liming. Journal of Hazardous Materials, Amsterdam v.160, p.228-234, 2008.

DUFFUS, J. H. "Heavy metal"- a meaningless term? Pure and Applied Chemistry, Durham, v.74, p.793-807, 2002.

FERNÁNDEZ-CALVIÑO, D.; SOLER-ROVIRA, P.; POLO, A.; ARIAS-ESTÉVEZ, M.; PLAZA, C. Influence of humified organic matter on copper behavior in acid polluted soils. Environmental Pollution, Oxford, v.158, p.3634-41, 2010.

FERREIRA, P.A.; BRUNETTO, G.; GIACHINI, A.J.; SOARES, C.R.F.S. Heavy metal remediation. In: GUPTA, D.K.; CHATTERJEE, S. (Ed.). Heavy metal remediation transport and accumulation in plants. New York: Nova Sciences Publishers, 2014, p.127-54.

FERREIRA, P.A.A.; LOPES, G.; BOMFETI, C.A.; OLIVEIRA, S.M.; SOARES, C.R.F.S.; GUILHERME, L.R.G.; MOREIRA, F.M.S Leguminous plants nodulated by selected strains of Cupriavidus necator grow in heavy metal contaminated soils amended with calcium silicate. World Journal of Microbiology and Biotechnology, Dordrecht, v.29, p.2055-66, 2013.

FLORES-VÉLEZ, L.M.; DUCAROIR, J.; JAUNET, A.M.; ROBERT, M. Study of the distribution of copper in an acid sandy vineyard soil by three different methods. European Journal of Soil Science, Oxford, v.47, p.523-32, 1996.

GIL-CARDEZA, M.L.; FERRI, A.; CORNEJO, P.; GOMEZ, E. Distribution of chromium species in a Cr-polluted soil: presence of $\mathrm{Cr}(\mathrm{III})$ in glomalin related protein fraction. Science of the Total Environment, New York, v.493, p.828-33, 2014.

GIROTTO, E.; CERETTA, C.A.; BRUNETTO, G.; RHEINHEIMER, D.S.; SILVA, L.S.; LORENSINI, F.; LOURENZI, C.R.; VIEIRA, R.C.B.; SCHMATZ, $\mathrm{R}$. Acúmulo e formas de cobre e zinco no solo após aplicações sucessivas de dejeto líquido de suínos. Revista Brasileira de Ciência do Solo, Viçosa, MG, v.34, p.955-65, 2010. 
GIROTTO, E.; CERETTA, C.A.; BRUNETTO, G.; MIOTTO, A.; TIECHER, T.L.; DE CONTI, L.; LOURENZI, C.R.; LORENSINI, F.; GUBIANI, P.I.; SILVA, L.S.; NICOLOSO, F.T. Copper availability assessment of $\mathrm{Cu}$-contaminated vineyard soils using black oat cultivation and chemical extractants. Environmental Monitoring and Assessment, Dordrecht, v.1, p.1-2, 2014.

GRABER, I.; HANSEN, J.F.; OLESEN, S.E.; PETERSEN, J.; ØSTERGAARD, H.S.; KROGH, L. Accumulation of copper and zinc in danish agricultural soils in intensive pig production areas. Danish Journal of Geography, Kóbenhavn, v.105, p.15-22, 2005.

HIRSCH, R.E.; LEWIS, B.D.; SPALDING, E.P.; SUSSMAN, M.R. A role for the AKT1 potassium channel in plant nutrition. Science, Washington, v.280, p.918-21, 1998.

JABEEN, R.; AHMAD, A.; IQBAL, M. Phytoremediation of heavy metals: physiological and molecular mechanisms. Botanical Review, Dordrecht, v.75, p.339-64, 2009.

JONES, D.L.; DARRAH, P.R. Role of root derived organic acids in the mobilization of nutrients from the rhizosphere. Plant and Soil, The Hague, v.166, p.247-57, 1994.

JONER, E.J.; BRIONES, R.; LEYVAL, C. Metalbinding capacity of arbuscular mycorrhizal mycelium. Plant and Soil,The Hague, v.226, p.227-34, 2000.

KALDORF, M.O.; KUHN, A.J.; SCHRÖDER, W.H.; HILDEBRANDT, U.; BOTHE, H. Selective element deposits in maize colonized by a heavy metal tolerance conferring arbuscular mycorrhizal fungus. Journal of Plant Physiology, New York, v.154, p.718-28, 1999.

KIRKHAM, M.B. Cadmium in plants on polluted soils: effects of soil factors, hyperaccumulation, and amendments. Geoderma, New York, v.137, p.19-32, 2006.

KOMÁREK, M.; CADKOVÁ, E.; CHRASTNÝ, V.; BORDAS, F.; BOLLINGER, J.C. Contamination of vineyard soils with fungicides: a review of environmental and toxicological aspects. Environment International, New York, v.36, p.138-51, 2010.
MA, J.F.; YAMAJI, N. Functions and transport of silicon in plants. Cellular and Molecular Life Sciences, Basel, v.65, p.3049-57, 2008.

MEIER, S.; ALVEAR, M.; BORIE, F.; AGUILERA, P.; GINOCCHIO, R.; CORNEJO, P. Influence of copper on root exudate patterns in some metallophytes and agricultural plants. Ecotoxicology and Environmental Safety, Orlando, v.75, p.8-15, 2012.

MIOTTO, A.; CERETTA, C. A.; BRUNETTO, G.; NICOLOSO, F.; GIROTTO, E.; FARIAS, J.; TIECHER, T.; DE CONTI, L.; TRENTIN, G. Copper uptake, accumulation and physiological changes in adult grapevines in response to excess copper in soil. Plant and Soil, The Hague, v.374, p.593-610, 2014. (

LI, P.; WANG, X. X.; ZHANG, T. L.; ZHOU, D.; HE, Y. Q. Effects of several amendments on rice growth and uptake of copper and cadmium from a contaminated soil. Journal of Environmental Sciences, Los Angeles, v.20, p.449-455, 2008.

MORSOMME, P.; BOUTRY, M. The plant membrane $\mathrm{H}+$-ATPase: structure, function and regulation. Biochimica et Biophysica Acta, Amsterdam, v.1465, p.1-16, 1999.

NAGAJYOTI, P. C.; LEE, K. D.; SREEKANTH, T. V. M. Heavy metals, occurrence and toxicity for plants: a review. Environmental Chemistry Letters, Berlin, v.8, p.199-216, 2010.

NEILSEN, D.; HOYT, P.B.; MacKENZIE, A.F. Distribution of soil $\mathrm{Zn}$ fractions in Bristish columbia interior orchard soils. Canadian Journal Soil Science, Ottawa, v.66, p.445-54, 1986.

PÉREZ-ESTEBAN, J.; ESCOLÁSTICO, C.; MASAGUER, A.; VARGAS, C.; MOLINER, A. Soluble organic carbon and $\mathrm{pH}$ of organic amendments affect metal mobility and chemical speciation in mine soils. Chemosphere, Oxford, v.103, p.164-71, 2014.

PICH, A.; SCHOLZ, G.; STEPHAN, U.W. Irondependent changes of heavy metals, nicotianamine, and citrate in different plant organs and in the xylem exudate of two tomato genotypes. Nicotianamine as possible copper translocator. Plant and Soil, The Hague, v.165, p.189-96, 1994. 
PIETRZAK, U.; MCPHAIL, D.C. Copper accumulation, distribution and fractionation in vineyard soils of Victoria, Australia. Geoderma, New York, v.122, p.151-66, 2004.

PII, Y.; MIMMO, T.; TOMASI, N.; TERZANO, R.; CESCO, S.; CRECCHIO, C. Microbial interactions in the rhizosphere: beneficial influences of plant growthpromoting rhizobacteria on nutrient acquisition process. A review. Biology and Fertility of Soils, Berlin, v.51, p.403-15, 2015.

PUNZ, W.F.; SIEGHARDT, H. The response of roots of herbaceous plant species to heavy metals. Environmental and Experimental Botany, Amsterdam, v.44, p.85-98, 1993.

RAMALHO, J.F.G.P.; AMARAL SOBRINHO, N.M.B.; VELLOSO, A.C.X. Acúmulo de metais pesados em solos cultivados com cana de açúcar pelo uso contínuo de adubação fosfatada e água de irrigação. Revista Brasileira de Ciência do Solo, Viçosa, MG, v.2, p.971-9, 1999.

RAUSER, W.E. Structure and function of metal chelators produced by plants. Cell Biochemistry and Biophysics,Totowa, v.31, p.19-48, 1999.

ROSA, D.J.; AMBROSINI, V.G.; BASSO, A.; BORGHEZAN, M.; BRUNETTO, G.; PESCADOR, R. Photosynthesis and growth of young -Niágara Branca- vines (Vitis labrusca L.) cultivated in soil with high levels of copper and liming. BIO Web of Conferences, Les Ulis, v.3, p.1-4, 2014.

SENDEN, M.H.M.; WOLTERBEEK, H.A.T. Effect of citric acid on the transport of cádmium through xylem vessels of excised tomato stem-leaf systems. Acta Botanica Neerlandica, Wageningen, v.39, p.297-303, 1990.

SENDEN, M.H.M.; VAN DER MEER, A.J.G.M.; VERBURG, T.G.; WOLTERBEEK, H.T. Citric acid in tomato plant roots and its effect on cadmium uptake and distribution. Plant and Soil, The Hague, v.171, p.333-9, 1995.

SETH, C.S. Areview on mechanisms of plant tolerance and role of transgenic plants in environmental cleanup. Botanical Review, Dordrecht, v.78, p.32-62, 2012.
SHAW, A.J. Heavy metal tolerance in plants: evolutionary aspects. New York: CRC Press, 1989.

TESSIER, A.; CAMPBEL, P.G.C.; BISSON, M. Sequential extraction procedure for the speciation of particulate trace metals. Analytical Chemistry, Washington, v.51, p.844-51, 1979.

TIECHER, T.; BRUNETTO, G.; CERETTA, C.A.; COMIN, J.J.; GIROTTO, E.; MIOTTO, A.; MORAES, M.P.; BENEDETT, L.; FERREIRA, P.A.; LOURENZI, C.R.; COUTO, R.R. Forms and accumulation of copper and zinc in a sandy Typic Hapludalf soil after long-term application of pig slurry and deep litter. Revista Brasileira de Ciência do Solo, Viçosa, MG, v.37, p.812-24, 2013.

TOSELLI, M.; BALDI, E.; MARCOLINI, G.; MALAGUTI, D.; QUARTIERI, M.; SORRENTI, G.; MARANGONI, B. Response of potted grapevines to increasing soil copper concentration. Australian Journal of Grape and Wine Research, Glen Osmond, v.15, p.85-92, 2009.

TOSELLI, M.; BALDI, E.; MARCOLINI, G.; MALAGUTI, D.; QUARTIERI, M.; SORRENTI, G.; MARANGONI, B. Response of potted pear trees to increasing copper concentration in sandy and clayloam soils. Journal of Plant Nutrition, New York, v.31, p.2089-104, 2008.

VAVOULIDOU, E.; AVRAMIDES, E.J.; PAPADOPOULOS, P.; DIMIRKOU, A.; CHAROULIS, A. KONSTANTINIDOUDOLTSINIS, S. Copper content in agricultural soils related to cropping systems in different regions of Greece. Communications in Soil Science and Plant Analysis, New York, v.36, p.759-73, 2005.

ZHANG, C.; WANG, L.; NIE, O.; ZHANG, W.; ZHANG, F. Long-term effects of exogenous silicon on cadmium translocation and toxicity in rice (Oryza sativa L.). Environmental and Experimental Botany, Amsterdam, v.62, p.300-7, 2008.

ZHANG, L.; PAN, Y.; LV, W.; XIONG, Z.T. Physiological responses of biomass allocation, root architecture, and invertase activity to copper stress in young seedlings from two populations of Kummerowia stipulacea (maxim.) Makino. Ecotoxicology and Environmental Safety, Orlando, v.104, p.278-84, 2014. 